\title{
Impact of Excise Tax Hike to Stock Value (A Case Study of PT. Hanjaya Mandala Sampoerna, Tbk.)
}

\author{
Putu Bagus Adhi Wijaya and Erman Sumirat
}

\begin{abstract}
Cigarette industry in Indonesia had contributed around $8 \%$ to the state revenue in $\mathbf{2 0 1 8}$, and this number are expected to increase in $\mathbf{2 0 2 0}$ due to higher excise tax rate for cigarette industry which believed can boost the state revenue. However, the cigarette's excise tax hike that will be effective in January $1^{\text {st }}, 2020$ will have significant impact to all of the cigarette companies in Indonesia. The biggest cost of goods sold component of cigarette companies were the excise tax expense, thus, a significant increase on excise tax will reduce the company's profitability. The significant decrease in company's profitability could affect the company's stock performance. In order to help the investors how to react to this situation, the intrinsic valuation of the company is required. Evaluating the company's financial performance in the past five years and conducting absolute or often called intrinsic valuation of HMSP are believed to be important in order to help the investors how to act while the cigarette companies' stock was all tumbled since the beginning of the year. This study examined absolute valuation of HMSP using the FCFE model. Absolute valuation models were calculated and had suggested that the current stock price of IDR 1,900 of HMSP is undervalued. The intrinsic value calculated from absolute valuation models was IDR 2,242.71. FCFE models show significantly high intrinsic value for HMSP, with potential return above $15 \%$, it should attract the prospective investors to buy the company's stock.
\end{abstract}

Index Terms - excise tax, absolute valuation, monte carlo simulation, Sampoerna.

\section{INTRODUCTION}

Southeast Asia Tobacco Control Alliance (SEATCA) report titled "The Tobacco Control Atlas", ASEAN Region shows that Indonesia is the country with the highest number of smokers in ASEAN, which is 65.19 million people, followed by Philippines with 16.5 million people. The tobacco industry offers numerous employment opportunities and plays a significant role in government income. In 2018, cigarette excise tax contributes IDR 153 Trillion to the state revenue. Indonesia state revenue are around IDR 1,942 Trillion, which means cigarette industry contributes $8 \%$ to the state revenue. This number are expected to increase in 2020 due to higher excise tax rate for cigarette industry so that can boost the state revenue. Data from Ministry of Industry, said that 5.98 million employment are absorbed by the cigarette industry, which is divided into manufacturing, distribution, and plantation sector. The number of employees provides large contribution in order to reduce the number of unemployed in Indonesia.
PT. Hanjaya Mandala Sampoerna, Tbk (HMSP) is one of cigarette company that listed in Indonesia Stock Exchange. One of the biggest factors that have impact to HMSP's performance is excise tax, because around 75\% of HMSP's cost of goods sold comes from the excise tax expense. Since 2011, there is seven times excise tax hike as shown in Figure 1 below.

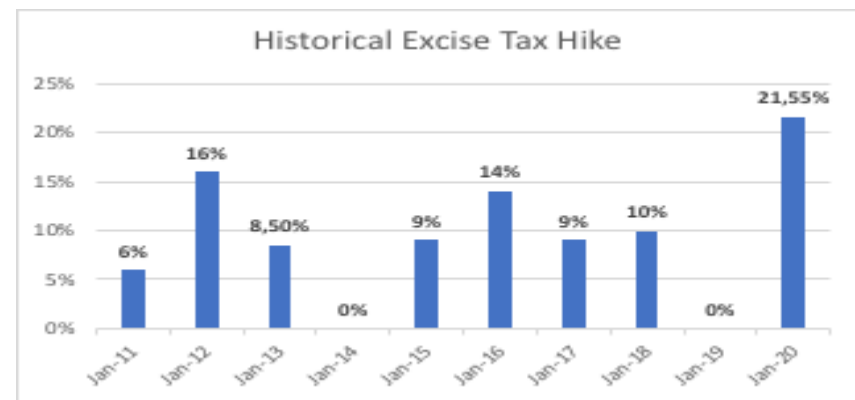

Fig. 1. Historical Excise Tax Hike

Cigarette company stock price is very correlated with excise tax, as seen in current price of HMSP and GGRM (PT. Gudang Garam Tbk). HMSP stock price already declining from IDR 3,770 in January $2^{\text {nd }}, 2019$, into IDR 1,900 in November $28^{\text {th }}, 2019$, declining by $49.6 \%$. Meanwhile GGRM are declining by $41.2 \%$ on the same period. This decline is due to analyst predict that the increase in COGS and cigarettes price are not accompanied by the increase of cigarettes sales volume, which believed will have an impact to the company's profitability. It's not the first time the government increasing the excise tax for cigarette company. But this is the first time that the market reacts negatively to the increase of the excise tax.

\section{LITERATURE REVIEW}

\section{A. Business Situation Analysis}

There are some techniques that widely used to conduct external analysis, such as PESTLE analysis, and Porter's Five Force analysis. Internal analysis is carried out using the VRIN framework by previously identifying the resources and capabilities of HMSP. SWOT analysis were also conducted in order to give conclusion of current external and internal analysis of HMSP.

The political environment in cigarette industry in Indonesia is highly regulated due to the government main purpose which is to reduce the number of active smokers in Indonesia, especially for the underage. 
The practice of this regulation are shown by Indonesia's cigarette excise tax hike since 2011. This regulation affect all of the cigarette company in Indonesia, making the production volume in a downtrend every year since the regulations applied. For example, in 2015 Indonesia's total cigarettes production is around 320 billion sticks per year, meanwhile in 2018 declining into 307 billion sticks per year.

For the internal analysis, using VRIN framework, there is some current capabilities which were considered sustainable for HMSP, which is strong brand value, product flavors and quality, inventory management systems set up for high efficiency, and economies of scale. From the competitor financial ratio analysis also shown that HMSP is better in term of liquidity and profitability. HMSP have better Return on Equity and Net Profit Margin compared to the competitor, which means HMSP is more effective and efficient in managing their assets.

SWOT analysis is carried out after conducting external and internal analysis for HMSP competitive position and formulating a strategy. SWOT analysis is shown in the table below.

TABLE I: SWOT ANALYSIS OF HMSP

\begin{tabular}{|c|c|}
\hline STRENGTHS & WEAKNESSES \\
\hline $\begin{array}{l}\text { 1. Strong brand value, HMSP has } \\
\text { been the king of Indonesia's } \\
\text { cigarette market share for } 14 \\
\text { years in a row with currently } 33 \% \\
\text { market share. } \\
\text { 2. Wide distribution channel with } \\
115 \text { sales office and distribution } \\
\text { center all over Indonesia. } \\
\text { 3. Effective and efficient, compared } \\
\text { to its competitor, HMSP were } \\
\text { very effective using their assets, } \\
\text { it could be seen from the Return } \\
\text { on Equity and Total Assets } \\
\text { Turnover ratio. }\end{array}$ & $\begin{array}{l}\text { 1. Lack of Innovation, still rely on } \\
\text { their old products. The company } \\
\text { also have e-cigarette called } \\
\text { IQOS, but HMSP is a bit late to } \\
\text { release their product in Indonesia, } \\
\text { while JUUL already sold similar } \\
\text { product. } \\
\text { 2. Premium price, it is true that } \\
\text { HMSP have high number of loyal } \\
\text { consumer, but there is also a } \\
\text { price-sensitive consumer which } \\
\text { are willing to switch to other } \\
\text { cheaper cigarette brands which } \\
\text { have similar quality. }\end{array}$ \\
\hline OPPORTUNITIES & THREATS \\
\hline $\begin{array}{l}\text { 1. Retail store growing rapidly in } \\
\text { the last } 5 \text { year, making the } \\
\text { company's distribution channel } \\
\text { wider. }\end{array}$ & $\begin{array}{l}\text { 1. Government tight regulations. The } \\
\text { excise tax trends tend to increase } \\
\text { every year making the cigarette } \\
\text { company's profit margin thinner. }\end{array}$ \\
\hline $\begin{array}{l}\text { 2. Indonesia Drug and Food Control } \\
\text { Agency (BPOM) in November } \\
2019 \text { propose a ban on vape and } \\
\text { e-cigarettes due presence of } \\
\text { dangerous chemicals in it }\end{array}$ & $\begin{array}{l}\text { 2. Although it is not regulated yet, } \\
\text { but vape and e-cigarette should } \\
\text { be considered as threats for } \\
\text { traditional cigarette business. }\end{array}$ \\
\hline
\end{tabular}

\section{B. Valuation}

Absolute value is related to the intrinsic characteristic of a company or an asset, which is why it is often called as an intrinsic value. However, an absolute valuation model needs so many explicit inputs, which might lead to data manipulation. An intrinsic value is commonly calculated using a discounted cash flow (DCF) valuation model. Using this model, the intrinsic value of is a representation of expected cash flow in the future that are discounted to their present value with a certain required return. Absolute valuation models needs several assumption for the input, such as discount rates and terminal growth in order to determine the terminal value. The absolute valuation model used in this study was the Free Cash Flow to Equity (FCFE) model, the absolute value generated from this study would be compared with HMSP's current stock price, the output would be either the stock is undervalued or overvalued.

\section{Methodology}

Data collection and methodology is very important in every research. Generally, there are two types of data, primary and secondary data. Primary data refers to the first hand data that were original, and self-retrieved, whereas secondary data means data that usually statistically processed, experienced and retrieved by the other party. In this study, type of data used were mostly secondary data such as company financial statements, annual report, public expose report and the company fact sheet. External data such as press news that might be related to this study was also employed accordingly.

This study was using top-down approach. The starting point of this study after all of the business issue that was already stated in the previous chapter, internal and external analysis were conduct in order to gather information and help to understand the situational positioning of HMSP in the industry. PESTEL framework and Porter's Five Forces analysis were used in order to get a better understanding to the external factors of cigarette industry in Indonesia. VRIN framework and financial ratio analysis were conducted to analyse the internal condition of the company. SWOT analysis was also conducted to evaluate the environments and the company's business as a whole.

Absolute valuation model was used to propose business solution in this study. Absolute valuation was comprised by Free Cash Flow to Equity (FCFE). Absolute valuation models were used to calculate the intrinsic value of HMSP stocks. From the calculation could be determine, either the recommendation is to BUY, HOLD or SELL.

\section{Findings And ARgument}

\section{A. Revenue Projection}

HMSP's revenue was generated from the three major cigarettes category, which is machine-made kretek cigarette (SKM), hand-rolled kretek cigarette production facilities (SKT) and white cigarette (SPM). In forecasting the nominal revenue growth, the revenue broke down in two components, which is price and volume growth. For 2020F, the sales volume of SKM will dropped by $10 \%$ due to the increase of the retail price. Meanwhile for SPM and SKT will assumed to be dropped by $15 \%$. And the sales volume for $2021 \mathrm{~F}$ forward will be assumed to be the same as the 5 years average sales of each product. For the price, the assumption used is the minimum retail price recommended by the ministry of Finance.

\section{B. Cost of Goods Sold}

HMSP's cost of goods sold were dominated by excise tax expense, which contributed $75.48 \%$ from total COGS in 2018. Meanwhile the other $24.42 \%$ were consist of production cost, purchase of merchandise inventory and cost of other sales. As for the forecast COGS for 2019F-2029F, the approach used to calculated the COGS in this study was using percentage of sales, this is due to HMSP's COGS to sales in very stable in the last five years, thus the average five years percentage of sales were chosen, resulting $74.77 \%$, and this is assumed to be constant in valuation. 


\section{Operating Expenses}

For the selling and G\&A expenses assumption, the same approach used, which was using percentage of sales, as for selling expenses, the assumption used was the five years average of selling expenses to sales, which is $6.26 \%$, Meanwhile for the G\&A expenses for 2019F, the assumption is $1.83 \%$.

\section{Stock Beta}

Beta coefficients $(\beta)$ is a relative measure of a risk that cannot be diversified. This measures the movement of an asset's return that response to the change of the market return. Beta coefficient calculated using the regression analysis, the data were based on the 5-year weekly historical data of HMSP stocks return and the JKSE index (market) return. The regression analysis resulted on beta of 0.94 will be shown in Figure 2 below.

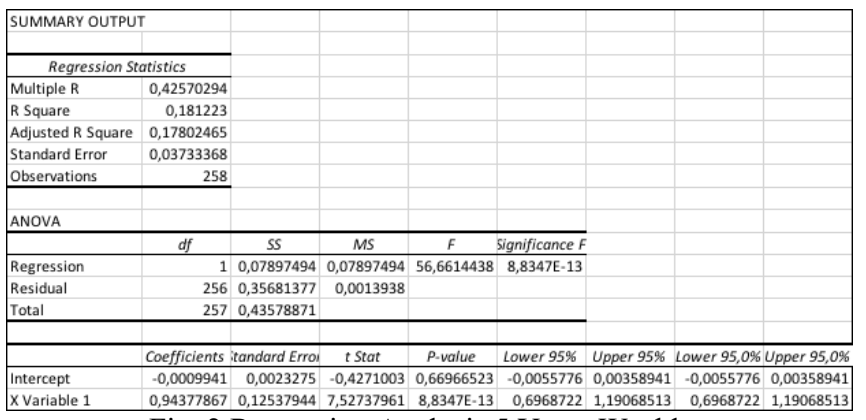

Fig. 2 Regression Analysis 5 Years Weekly.

\section{E. Discount Rate}

The Free Cash Flow to Equity (FCFE) was then discounted with certain required rate of return, in the FCFE model, the discount rate that were used is the company's cost of equity. The cost of equity that were used in this study was calculated using the Capital Asset Pricing Model (CAPM). CAPM links non-diversifiable risk to expected returns. The input required in order to calculate CPM were the beta coefficient, risk-free rate, and market return. For the risk-free rate, 10-years government bond yield were chosen due to the valuation time horizon is also 10 years, the current risk-free rate is $7.3311 \%$. The market return used were calculated using JKSE 10 years monthly return from December $23^{\text {rd }}, 2009$ - December $23^{\text {rd }}$, 2019 which is $10.4 \%$. According to this data, the cost of equity of HMSP from using CAPM is $10.23 \%$.

\section{F. Terminal Growth}

There are several methods to calculate the terminal value of a company, in this study, the cashflows of the firm were assumed to grow at a constant rate forever or the company were experiencing stable growth. Using the stable growth assumption, the terminal value can be estimated using perpetual growth model. Since there is no company whom can grow forever a rate higher than the economic growth rate in where the company operates, the constant growth rate can't be higher than the GDP growth rate of the country (Damodaran, 2006). In this study, the terminal growth that will be used is the Indonesia's GDP growth rate in 2018 which is $5.17 \%$.

\section{G. Result of Valuation}

Based on the FCFE model, the absolute value or often called as the intrinsic value of IDR 2,242.71 were acquired for each of HMSP's share that was sold to public, which provides potential gain/upside of $18.04 \%$ from the stock closing price of November $28^{\text {th }}, 2019$ which is IDR 1,900.

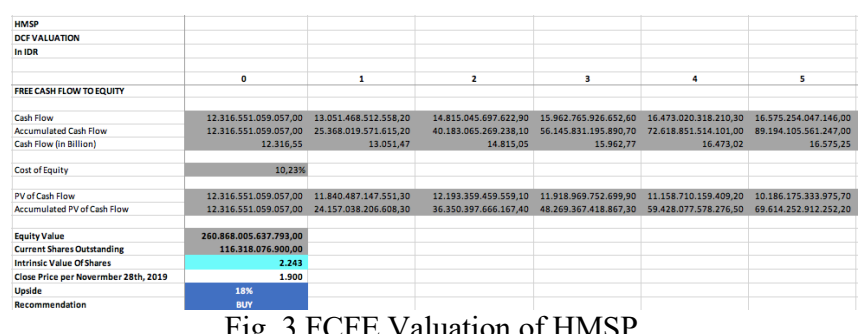

Fig. 3 FCFE Valuation of HMSP

\section{H. Sensitivity Analysis}

The main purpose of sensitivity analysis is to determine which assumption were important and have high impact to the output variability. Sensitivity analysis involves systematic change of an assumption on which projected financial model is based and observing how the forecast responds. Sensitivity analysis done by changing the input variables using the "ceteris paribus" assumption meaning "other things held constant". Sensitivity analysis performed by implementing the $\pm 20 \%$ swing on the variables input. This affect the intrinsic value the FCFE model. Critical changes are where the intrinsic values change more than $10 \%$ will be considered as sensitive and will be asses for the monte carlo simulation in the next assessment. Based on the sensitivity analysis that have been conducted, there are several factors that considered to be sensitive and have big influence for the FCFE model:

1. Excise tax expense $( \pm 64.14 \%)$.

2. Return market $(-29.95 \%$ and $+73.04 \%)$.

3. SKM product price $( \pm 14.78 \%)$.

4. SKM sales volume $( \pm 14.78 \%)$.

5. Stock beta $(-11.16 \%$ and $14.31 \%)$.

6. Terminal growth rate $(-9.94 \%$ and $14.42 \%)$.

From the sensitivity analysis, shows that excise tax expense were the most influential factors that can changes HMSP's fair price, this is due to the excise tax expense was the biggest component of HMSP's COGS, increase in COGS could reduce the company's net profit, assuming the other component was ceteris paribus. Meanwhile SKM quantity and price is sensitive because SKM product have the biggest contribution to HMSP's revenue, in 2018, SKM product contributing $60,38 \%$ of HMSP's revenue. As for the beta and return market essentially constituted the cost of equity, which used as discount rates for the FCFE calculation. In addition, terminal growth rate also sensitive due the rate is used to assume the company's forever growth rate. The tornado chart is shown in Figure 4 below. 


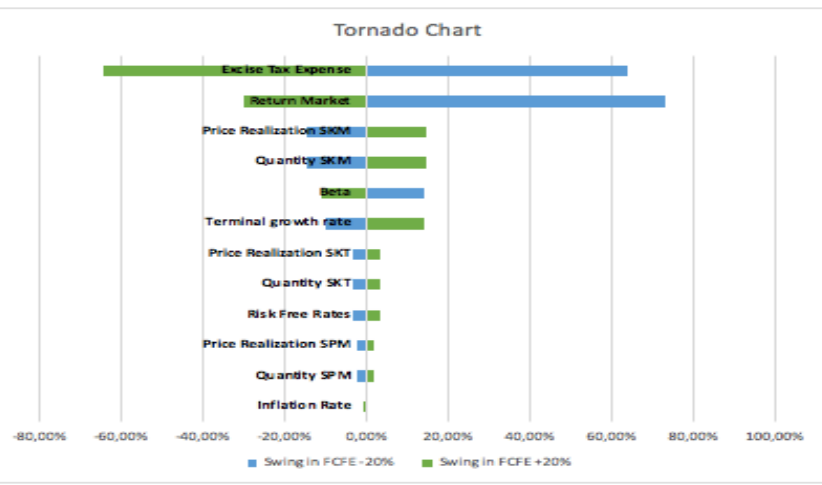

Fig. 4 Tornado Chart

\section{Monte Carlo Simulation}

Monte carlo simulation is a kind of simulation which calculates the result by repeating random sampling and statistical analysis. This simulation depends on several input parameters. These parameters are processed through the mathematical model and one or more outputs of the result. The study used monte carlo simulation to calculate the volatility of stock prices affected by sensitive inputs defined in the study. The method used for each parameter is the triangle distribution approach. The final output of this simulation is the stock's recommendation probability. According to the result of simulations, there is $52.4926 \%$ BUY probability that means HMSP intrinsic value for above IDR 2,185 (which is based on CFA Threshold standard that is $15 \%$ above the stock current price of IDR 1,900). Meanwhile the probability for HOLD $( \pm 15 \%$ from current market price) is $43.5845 \%$. And probability for SELL (intrinsic value below IDR 1,615) is only $3.9229 \%$. The graphs of monte carlo simulations were shown in Figure 5, Figure 6, and Figure 7.

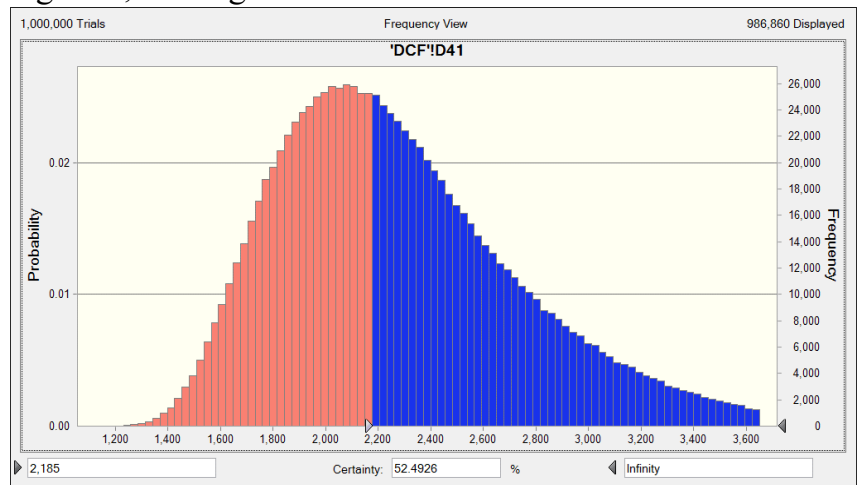

Fig. 5 Monte Carlo Simulation for BUY Recommendation

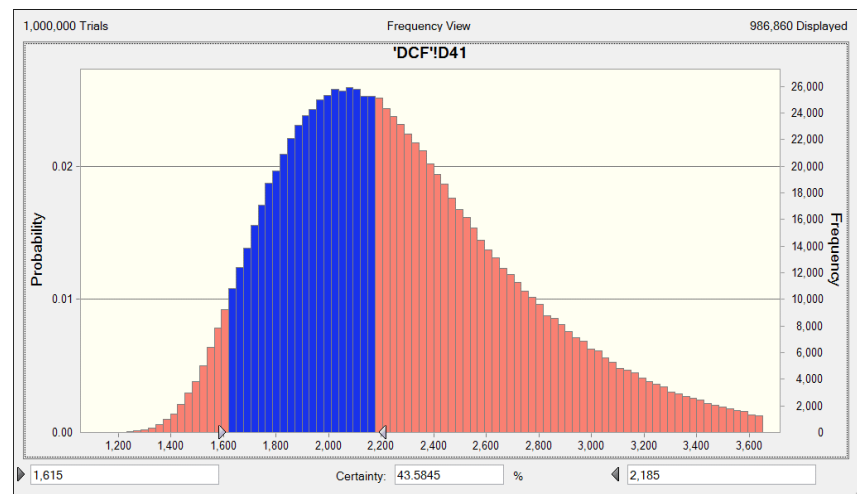

Fig. 6 Monte Carlo Simulation for HOLD Recommendation

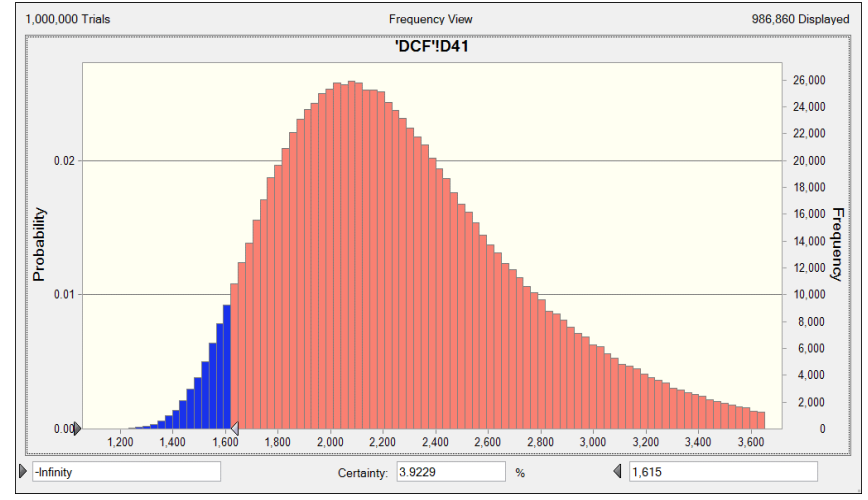

Fig. 7 Monte Carlo Simulation for SELL Recommendation

\section{CONCLUSION AND RECOMMENDATION}

\section{A. Conclusion}

From the external scanning shows that the most important factors that might hold back investors to invest in the company was the tight government regulation which tends to increase every year which can affect the company's profitability in the future. The other factor is the high rivalry in Indonesia's cigarette industry between HMSP, GGRM, RMBA, WIIM and Djarum (not listed in the Indonesia Stock Exchange), which gave the consumer many options in switching their product with very low-switching cost.

Despite the unfavorable condition, after seven times excise tax hike from the government since 2011-2019, the company's profitability ratio, especially the gross profit margin was still relatively stable, even there is a slightly decrease during the same periods. It's also happened with the other's cigarette company such as GGRM, RMBA and WIIM. It is possible because cigarettes are already like a primary need in Indonesia. In 2016, Indonesia's Ministry of Health Data Center (Infodatin) have done some research about what people tends to buy with their current salary, the result shown that peoples in both rural and urban area spends $11.91 \%$ of their monthly income for cigarettes, more than money they spends in nutritional foods such as beef (9.84\%), fish (7.19\%) and vegetables (7.27\%) (Infodatin, 2016).

This study examined the valuation process using absolute valuation models. An absolute valuation model was used to determine the value of the company. The FCFE method was chosen to calculate the intrinsic value of HMSP. The absolute valuation models show that the current (November $28^{\text {th }}, 2019$ ) stock price of HMSP (IDR 1,900) was undervalued compared to the intrinsic value (IDR 2,242.71). Sensitivity analysis and Monte Carlo simulations were performed to understand the effect of each parameter on HMSP values due to changes in economic conditions. From one million Monte Carlo simulation trials, the certainty of $15 \%$ upside from the current stock price was $52.49 \%$

\section{B. Recommendation}

It is very rare opportunity to witness the decline of such a great stock of a great company like HMSP. The recommendation is will be used for investors who have interest on investing their money in cigarette industry, especially HMSP, based on the result of the analyses which already provided from the previous chapter. The buy, hold, and sell recommendation used was the CFA's standard. Intrinsic value above $15 \%$ from the stock's current market 
price would result a BUY recommendation, intrinsic value between $-15 \%$ to $15 \%$ from the stock's current market price would result a HOLD recommendation and if the intrinsic value were below $-15 \%$ from the stock's current market price would resulting a SELL recommendation.

Absolute valuation models were already exhibited the potential upside above $15 \%$ from the stock's current market price (November $28^{\text {th }}, 2019$ ) of IDR 1,900, the intrinsic value from absolute valuation models were IDR 2,242.71. Thus, the final recommendation for the prospective investors was to BUY the HMSP stocks.

\section{REFERENCES}

[1] Annual Report. (2014-2018). PT Hanjaya Mandala Sampoerna Tbk.

[2] Barney, J. (1991). Firm Resources of Sustained Competitive Advantage. Journal of Management, 99-120.

[3] Bringham, E. (2007). Fundamentals of Financial Management. Cincinnati: Thomson Southwestern.

[4] Damodaran, A. (2006). Growth Rates and Terminal Value. Retreived from NYU Stern School of Business: http://people.stern.nyu.edu/adamodar/pdfiles/ovhds/dam2ed/growthan dtermvalue.pdf

[5] Gitman, L. (2015). Principles of Managerial Finance 14th ed. Boston: Pearson.

[6] Infodatin. (2016). The General Situation of Tobacco Consumption Indonesia. Jakarta: Ministry of Health Indonesia.

[7] Rothaermel, F. T. (2013). Strategic Management : Concepts and Cases. New York, NY: McGraw-Hill/Irwin.

[8] Wheelen, T. L. (2010). Concepts in Strategic Management \& Business Policy 12th Edition. Pearson.

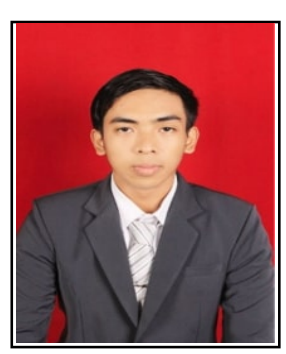

Putu Bagus Adhi Wijaya was born in Denpasar, $7^{\text {th }}$ of June 1996. He earned his bachelor's degree in Accounting from Undiknas University. He is currently pursuing his master's degree in Business Administration from Institut Teknologi Bandung majoring in Business Risk and Finance. He has work experience as an intern at PT PLN Persero in 2015 as a finance staff. Also, in 2019 at PT. BCA Securities as an Equity Analyst intern.

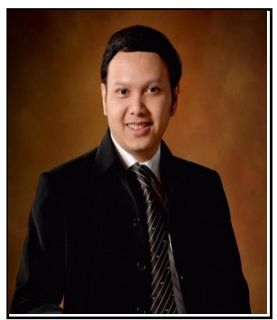

Erman Sumirat is currently a lecturer at the School of Business and Management Institute of Technology Bandung (SBM ITB). He received a MBuss in Finance from Monash University. Erman is also a Certified Securities Analys (CSA) and Certfied Risk Professional (CRP) holder.

Research areas that he focuses on include Islamic Banking, Islamic Finance, Corporate Finance, Business Risk Management, and Economics. In addition, the teaching area he has mastered includes Corporate Finance, Business Risk and Capital Market, Business Economics, Financial Management 